\title{
Anticancer Evaluation of Plants from Indonesian Tropical Rain Forests
}

\author{
Jamilah Abbas ${ }^{*}$ \\ Research Centre for Chemistry, Indonesian Institute of Sciences \\ PUSPIPTEK. Serpong. 15314. Indonesia
}

\begin{abstract}
The anticancer activities of medicinal plants from Indonesia's tropical rainforests were investigated against Hela cell line. Maytenfoliol from leaves of Calophyllumtetrapterum 3epibetulinic acid from stem bark of $C$. tomentosum Wight and D.A-friedo-oleanan-3-on from stem bark of $C$. moonii showed anticancer activity. The compound 3-epibetulinic acid showed the more potent anticancer activity than maytenfoliol and D.A-friedo-oleanan-3- with thean $\mathrm{IC}_{50}$ value were $3.17 \mu \mathrm{g} / \mathrm{mL}, 4.89 \mu \mathrm{g} / \mathrm{mL}$ and $5.63 \mu \mathrm{g} / \mathrm{mL}$, respectively.
\end{abstract}

Keywords: Anticancer evaluation, Hela cell line, Calophyllumtetrapterum. C. tomentosum Wight and C. moonii

\section{INTRODUCTION}

Cancer is the greatest human killer after cardiovascular disease. According to the World Health Organization (WHO) there are about 6 million people who suffer from disease each year, and resulting up to 15 deaths/100.000 patients. Cancer is caused by cell proliferation. Some factors such as carcinogenic chemicals, radioactive substances (UV ray, X ray), mutagenic reagents, virus and fast food cause have increasingly contributed to cancer cases every year. Until now, the treatment of cancer remains increasingly problematic and apparently the battle has not been successful (Marcus A.K et al., 1979 and Ross R., 1993). A currently popular approach to cancer therapy is through utilizing natural resources.

The genus Calophyllum is a member of Guttiferae (Clusiaceae) family. The Guttiferae family is well known to contain xanthones, coumarins, flavonoids and benzophenones. $C$. monii is a small tree and grown in lownlawn land. C. tetrapterum and tomentosum Wight are big trees reaching a heightof $33 \mathrm{~m}$ and $250 \mathrm{~cm}$ girth. The most popular species from the genus is the $C$. lanigerum since from it calanolida as an anti HIV1 have been successfully been isolated (Taher M et al., 2005).

The compound 4-phenylcoumarin have successfully been isolated from C. inophyllum $\mathrm{L}$. (guttiferae), and have activity as an antitumor agent, by examining their possibility of inhibitory effects on Epstein-Barr virus early antigen (EBVEA), activation induced by 12-Otetradecanoylphorbol-13-acetate in raji Cell (Itogawa et al., 2001). Herein we wish to report the isolation and structural elucidation of Maytenfoliol, 3-epibetulinic acid and D.A-friedooleanan-3-on as anticancer from the ethyl acetate extract of $C$. tetrapterum, $C$. tomentosum Wight and $C$. moonii respectively have been conducted. The genus Calophyllum which comprises 200 species is are widely distributed in the tropical rain forest where several species are used in folk medicine (Guilet D et al 2001). C. tetrapterum, $C$. tomentosum Wight and $C$. moonii are from the Tropical Rain Forest of the Indonesian continent (Soerianaga and Lemmens, 1994).

*Corresponding author e-mail : jamilahabbas@yahoo.com 


\section{MATERIALS AND METHODS}

\section{General experimental materials and equipment}

${ }^{1} \mathrm{H}-\mathrm{NMR},{ }^{13} \mathrm{C}-\mathrm{NMR}$ one $1 \mathrm{D}$, and two dimensional spectrum 2D type JNM-ECA-400 were observed using NMR-spectrophotometer type JNM-ECA-400, from Jeol with $500 \mathrm{MHz}$ in, $\mathrm{CDCl}_{3}$ was used as solvent : $\partial$ (ppm).LC-MS

Mariner Biored $(70 \mathrm{eV})$. FTIR type Prestige 21 Shimadzu (KBr pellets), spectrophotometer UVVIS prepared by using Hitachi model $2000 \mathrm{U}$ with $\mathrm{MeOH}$ and or $\mathrm{CHCl}_{3}$ as a solvent. Fisher Scientific serial $903 \mathrm{~N} 0056$ was used for determined of melting point instrument. The following adsorbents were used for purification. TLC was conducted using Merck Kieselgel 60 F254. Column chromatography was carried out using: Merck Kieselgel 60 also usedas stationary phase and $\mathrm{H}_{2} \mathrm{SO}_{4}$ in $\mathrm{MeOH}$ as mobile phase and $\mathrm{FeCl}_{3}$ as spraying reagent.

\section{Plant material}

The stem bark of $C$. monniwere collected from Jayapura, Papua, C. tomentosum Wight from Bogor, West Java and leaves of $C$. tetrapterum fromKerinci district, Riau-Jambi Province, West Sumatra. The samples were then authenticated by Ismail Rahman. The voucher specimen of plant material were deposited at the Herbarium of Botanical Research Institute, Indonesian Institute of Science, Bogor, Indonesia.

\section{Cell line and reagents}

Hela cell line was obtained from Japan, Eangle's medium (Nissui), foetal serum (Flow laboratories), Glutamin (Nissui/Sigma). Other chemical reagents were of analytical grade.
$\mathrm{NaHCO}_{3}$, methanol, ethanol, $n$-hexane, ethyl acetate, chloroform was purchased from local market.

\section{Bioasssay anticancer}

Preparation of medium

Medium formula prepared as below:

- $47 \mathrm{~g}$ Eangles MEM medium (Nissui) are dissolved in $475 \mathrm{~mL} \mathrm{H}_{2} \mathrm{O}$ (solvent $\mathrm{A}$ )

- $13 \mathrm{~g} \mathrm{NaHCO}_{3}$ (E Merck) are dissolved in $50 \mathrm{~mL}$ $\mathrm{H}_{2} \mathrm{O}$ and added $0.3 \mathrm{~g}$ glutamine (Nissui) (solvent B)

- $25 \mathrm{~mL}$ solvent $\mathrm{B}$ was added to solvent $\mathrm{A}$, and filtered by Millipore, these medium stored until used

For bioassay purpose: $15 \mathrm{ml}$ foetal serum (flow laboratories) was added to $85 \mathrm{ml}$ medium. The medium containing serum was used for bioassay test and initial cell amount $100 \times 10^{4}$ cell $/ \mathrm{mL}$.

\section{Bioasssay test (Yoo, T.J (1999)}

The anticancer assays were carried out in against Hela cell lines. The bioassays were performed in the multi-well plate tissue culture (1 $\mathrm{mL}$ cell/well). Five various doses of the samples $(0 ; 0.8 ; 1.6 ; 3.2$ and $6.4 \mu \mathrm{g} / \mathrm{mL})$ were diluted in methanol and $1 \mathrm{ml}$ methanol was used as control. The samples and control were added to the cells and were incubated during $48 \mathrm{~h}$ in $\mathrm{CO}_{2}$ incubator at $37^{\circ}$ C. After incubation, cell growth was calculated by microscope haemocytometer Fuch Rosentral. The cultured cells were treated at five concentrations of pure test compounds ranging $(0$; $0.8 ; 1.6 ; 3.2$ and $6.4 \mu \mathrm{g} / \mathrm{mL}$ ). Initial cell amount of $100 \times 10^{4}$ cell $/ \mathrm{mL}$. Percentage of inhibition cancer cell lines by three compounds were calculated as:

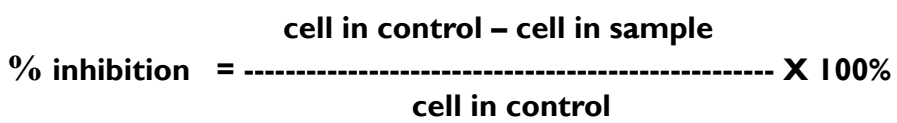

$\mathrm{IC}_{50}$ value was defined as the concentration of to $50 \%$ of the control. sample necessary needed to inhibit the cell growth 


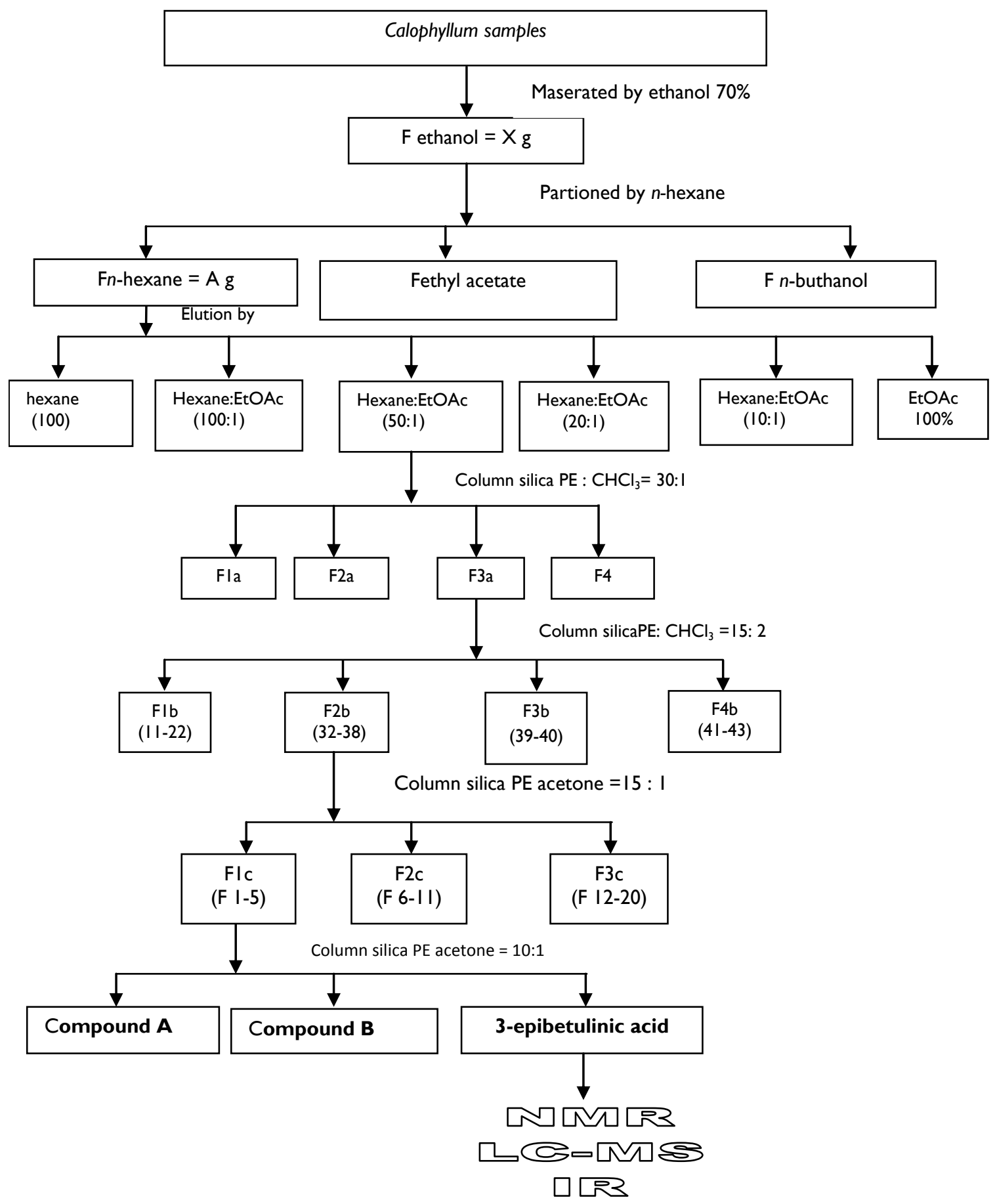

Figure I. Scheme of extraction and isolation of plant materials 


\section{RESULTS AND DISCUSSION}

\section{Compound I (maytenfoliol)}

Compound 1 (maytenfoliol) was obtained from leaves of $C$. tetrapterum as white needles with melting point at $300-302^{\circ} \mathrm{C}$. The infrared spectrum (KBr) showed absorption bands for carbonyls group at $1700 \mathrm{~cm}^{-1}$. The band at $1707 \mathrm{~cm}^{-1}$ assigned to carbonyl $(\mathrm{C}=\mathrm{O})$, for two alcohol at C-17 \& C-20 and one ketone. For C-3 and the band at $2920,2850 \mathrm{~cm}^{-1}$ were assigned to $\mathrm{C}-\mathrm{H}$ aliphatic stretching $(\mathrm{C}-3)$. The band at $3547 \mathrm{~cm}^{-1}$ was assigned as hydroxyl group. The presence of $\mathrm{C}-\mathrm{H}$ bending can be found at 1445, 1380, 1040 and $1010\left(\mathrm{~cm}^{-1}\right)$. Based on the ${ }^{1} \mathrm{H}$ NMR spectrum of compound $1\left(\mathrm{CDCl}_{3}\right.$ Table I) of compound 1 , it can be suggested that the compound 1 is maytenfoliol, $\mathrm{C}_{30} \mathrm{H}_{50} \mathrm{O}_{3} \mathrm{Mol}$ weight 458.2 .

${ }^{13} \mathrm{C}-\mathrm{NMR}\left(\mathrm{CDCl}_{3}\right): \partial 6.8(\mathrm{q}), 14.6(\mathrm{q})$, $18.0(\mathrm{q}), 18.3(\mathrm{t}) 19.0(\mathrm{q}), 19.2(\mathrm{q}), 22.2(\mathrm{t}), 28.1$. $(\mathrm{t}), 29.1(\mathrm{q}), 30.1(\mathrm{t}), 31.2(\mathrm{t}), 31.4(\mathrm{t}), 32.8(\mathrm{t})$, $33.3(\mathrm{t}), 34.2(\mathrm{~s}) 34.5(\mathrm{~s}) 35.1(\mathrm{t}) ; 35,39(\mathrm{~s}) ; 37,4$ (d); 38,1(s); 39,3(t); 41,2(t); 41,5(s);42,1(d); 52,4(d); 58,2(d); 59,4(t); 68.0(t); $213.2(\mathrm{~s}, \mathrm{C}=\mathrm{O})$

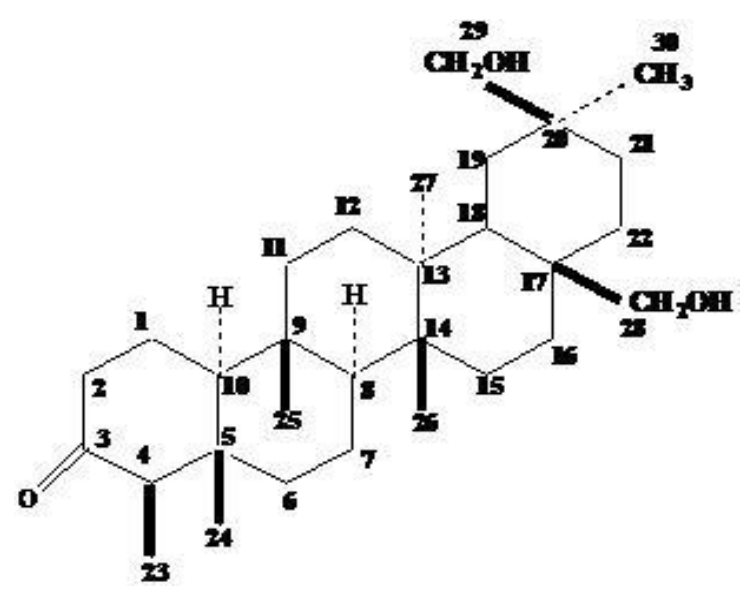

Figure 2. Structure of the Maytenfoliolmaytenfoliol

\section{Compound 2 (3-epibetulinic acid)}

Compound 2 (3-epibetulinic acid) was obtained from the stem bark of $C$. tomentosum Weigh as fine white crystal. Melting point 280$281^{\circ} \mathrm{C}, \quad$ MW: 456.711, Molecule formula $\mathrm{C}_{30} \mathrm{H}_{48} \mathrm{O}_{3}$ (calc 456.3603) $[\mathrm{M}]^{+}=456.711$. The infrared spectrum with $\mathrm{KBr}$ pellet showed absorption bands for hydroxyl (OH) at $v 3481 \mathrm{~cm}^{-}$ 1 indicating the presence of hydroxyl group $(\mathrm{OH})$. In addition, the spectrum showed the signal and for $\left(\mathrm{C}=\mathrm{CH}_{2}\right)$ at 2926, 1384, 780 indicating the presence of $\left(\mathrm{C}=\mathrm{CH}_{2}\right)$, and the signal for $\left(\mathrm{CO}_{2} \mathrm{H}\right)$ at 1707 indicating the presence of $\left(\mathrm{CO}_{2} \mathrm{H}\right)$. It is similar with 3-epibetulinic acid from reference (Sung, T.V et al., 1991): e.i $3440(\mathrm{OH}), 3070$, 1644, $890\left(\mathrm{C}=\mathrm{CH}_{2}\right), 1700\left(\mathrm{CO}_{2} \mathrm{H}\right)$.

The band at 0 2926, $2868 \mathrm{~cm}^{-1}$ were assigned to $\mathrm{C}-\mathrm{H}$ aliphatic stretching and the signals at $\mathrm{C}-\mathrm{H}$ bending at $\mathrm{O} 14501384,1361\left(\mathrm{~cm}^{-1}\right)$ indicating the presence of $\mathrm{C}-\mathrm{H}$ bending absorptions. The complete data of NMR spectrum can be found in the Table I In the ${ }^{1} \mathrm{H}$-NMR spectrum $\left(\mathrm{CDCl}_{3}\right)$ Table I ${ }^{1} \mathrm{HNMR}$ and ${ }^{13} \mathrm{C}$ NMR spectra data of compound 2 (3-epibetulinic acid). 
Table I. ' HNMR and ${ }^{13}$ CNMR spectra data of 3-epibetulinic acid. From From C. tomentosum Wight compared to reference

\begin{tabular}{|c|c|c|c|c|}
\hline \multirow[b]{2}{*}{ Carbon No } & \multicolumn{2}{|c|}{$\begin{array}{c}{ }^{13} \mathrm{C} \text { NMR } \\
\text { 3-epibetulinic }\end{array}$} & \multicolumn{2}{|c|}{$\begin{array}{c}\text { IH NMR } \\
\text { 3-epibetulinic } \\
\text { (m, } J \text { in } \mathrm{Hz})\end{array}$} \\
\hline & Sample & Reference & Sample & Reference \\
\hline 1 & $30,1(\mathrm{t})$ & $30,5(\mathrm{t})$ & & \\
\hline 2 & $29,2(t)$ & $29,0(t)$ & & \\
\hline 3 & $76,7(\mathrm{C}-\mathrm{OH})(\mathrm{d})$ & $76,9(\mathrm{C}-\mathrm{OH})(\mathrm{d})$ & $3,33(s) 2,94(\mathrm{I} \mathrm{H}, \mathrm{d}, 2,4)$ & $3,39(d, 2)$ \\
\hline 4 & $36,7(s)$ & $36,0(s)$ & - & - \\
\hline 5 & 49,9 (d) & 49,9 (d) & 2,2। (I H, d, II, 8:I2, 2:I2) & \\
\hline 6 & $17,9(\mathrm{t})$ & $17,9(t)$ & & \\
\hline 7 & $36,3(t)$ & $36,3(t)$ & & \\
\hline 8 & $38,5(s)$ & $38,5(s)$ & & \\
\hline 9 & 48,5 (d) & 48,5 (d) & $2, \mathrm{II}(\mathrm{IH}, d, 9,8)$ & \\
\hline 10 & $4 I, 9(s)$ & $4 I, 9(s)$ & & \\
\hline 11 & $25,0(\mathrm{t})$ & $25,0(\mathrm{t})$ & & \\
\hline 12 & $33,9(t)$ & $33,7(t)$ & & \\
\hline 13 & 46,6 (d) & 46,8 (d) & $2,97(\mathrm{IH}, \mathrm{d}, 6,4)$ & $2,32,(\mathrm{IH}, \mathrm{s})$ \\
\hline 14 & $38,5(s)$ & $38,4(s)$ & & \\
\hline 15 & $38,2(t)$ & $38,2(t)$ & & \\
\hline 16 & $27, I(t)$ & $27,0(\mathrm{t})$ & & \\
\hline 17 & $55,4(s)$ & $55,4(s)$ & & \\
\hline 18 & 37,6 (d) & 37,6 (d) & $\mathrm{I}, 77(\mathrm{IH}, \mathrm{d}, 6,8)$ & \\
\hline 19 & 54,8 (d) & 54,8 (d) & $\mathrm{I}, 80(\mathrm{IH}, d, 4)$ & $\mathrm{I}, 80(\mathrm{IH}, \mathrm{m})$ \\
\hline 20 & I50,3 (s) & 150,3 (s) & & \\
\hline 21 & $20,4(t)$ & $20,4(\mathrm{t})$ & & \\
\hline 22 & $31,6(t)$ & $31,6(t)$ & & \\
\hline 23 & I5,7 (q) & I6,I (q) & $0,76(3 \mathrm{H}, s)$ & $0,82(3 \mathrm{H}, s)$ \\
\hline 24 & 15,8 (q) & I5,I (q) & $0,64(3 \mathrm{H}, \mathrm{s})$ & $0,80(3 \mathrm{H}, s)$ \\
\hline 25 & 15,9 (q) & I6,2 (q) & $0,88(3 \mathrm{H}, \mathrm{s})$ & $0,95(3 \mathrm{H}, s)$ \\
\hline 26 & 14,4 (q) & I4,8 (q) & $0,88(3 \mathrm{H}, s)$ & $0,96(3 \mathrm{H}, s)$ \\
\hline 27 & 18,9 (q) & I8,। (q) & $0,93(3 \mathrm{H}, s)$ & $0,97(3 \mathrm{H}, s)$ \\
\hline 28 & I77,2 (COOH) & I 78,2 (COOH) & & \\
\hline $29 a$ & $109,6(t)$ & $107,1(t)$ & 4,56 (IH) & 4,60 (IH) \\
\hline $29 b$ & & & 4,68(IH) & 4,77 (IH) \\
\hline 30 & 28,2 (q) & 27,4 (q) & $\mathrm{I}, 64(3 \mathrm{H}, \mathrm{s})$ & $\mathrm{I}, 7 \mathrm{I}(3 \mathrm{H}, \mathrm{s})$ \\
\hline
\end{tabular}

\section{Compound 3 (D.A-friedo-oleanan-3-on)}

Compound 3 (D.A-friedo-oleanan-3-on) was obtained from the stem bark of C. moonii. 
Table II. I HNMR and ${ }^{13}$ CNMR spectra data of D.A-friedo-oleanan-3-on from sample was compare compared to references (Garmen, Lucia, 2000)

\begin{tabular}{|c|c|c|c|}
\hline \multirow[b]{2}{*}{ Carbon No } & \multicolumn{2}{|c|}{$\begin{array}{c}{ }^{13} \mathrm{C} \text { NMR } \\
\text { D.A-friedo-olenan-3-on }\end{array}$} & \multirow[b]{2}{*}{$\begin{array}{l}\text { Sample } \\
\delta_{\mathrm{H}}(\mathrm{ppm})\end{array}$} \\
\hline & $\begin{array}{l}\text { Reference } \\
\delta c(p p m)\end{array}$ & $\begin{array}{c}\text { Sample } \\
\delta c(p p m)\end{array}$ & \\
\hline I & $21,9(\mathrm{t})$ & $22,5(t)$ & $1,94-1,97$ \\
\hline 2 & $4 I, 2(t)$ & $4 I, 7(t)$ & \\
\hline 3 & $212,7(s)$ & $213,5(s)$ & \\
\hline 4 & 57,9 (d) & 58,4 (d) & 2,25 \\
\hline 5 & $4 I, 8(s)$ & $42,3(\mathrm{~s})$ & \\
\hline 6 & $4 I, 0(t)$ & $4 I, 5(t)$ & \\
\hline 7 & $17,9(\mathrm{t})$ & $18,4(t)$ & \\
\hline 8 & $52,8(d)$ & 53,3 (d) & \\
\hline 9 & 37,1 (s) & $37,6(s)$ & \\
\hline 10 & 59,2 (d) & 59,6 (d) & \\
\hline 11 & $35,7(t)$ & $35,8(t)$ & \\
\hline 12 & $29,3(t)$ & $30,7(t)$ & \\
\hline 13 & $30,0(s)$ & $39,9(\mathrm{~s})$ & \\
\hline 14 & $39,4(s)$ & $38,5(\mathrm{~s})$ & \\
\hline 15 & $32,5(t)$ & $32,6(t)$ & \\
\hline 16 & $35,3(t)$ & $36,2(t)$ & \\
\hline 17 & 29,7 (s) & 30,2 (s) & \\
\hline 18 & 42,5 (d) & 42,9 (d) & \\
\hline 19 & $35,0(t)$ & $35,5(t)$ & \\
\hline 20 & $27,8(4)$ & $28,4(4)$ & \\
\hline 21 & $32, I(t)$ & $32,9(t)$ & \\
\hline 22 & $38,9(\mathrm{t})$ & $39,4(\mathrm{t})$ & \\
\hline 23 & 4,6 (q) & 7,0 (q) & 0,88 \\
\hline 24 & 14,3 (q) & I4,8 (q) & 0,72 \\
\hline 25 & 17,6 (q) & I8,। (q) & 0,86 \\
\hline 26 & $18,3(q)$ & 20,5 (q) & 0,99 \\
\hline 27 & 19,9 (q) & I8,8 (q) & 1,04 \\
\hline 28 & 31,8 (q) & 32,0 (q) & 1,0 \\
\hline 29 & 34,7 (q) & 35,2 (q) & 0,95 \\
\hline 30 & 3I,5 (q) & 31,9 (q) & 1,18 \\
\hline
\end{tabular}




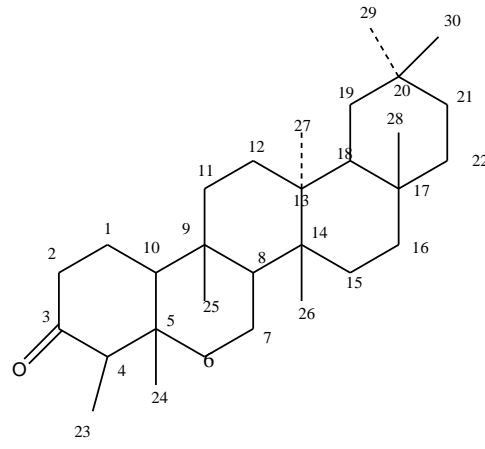

A

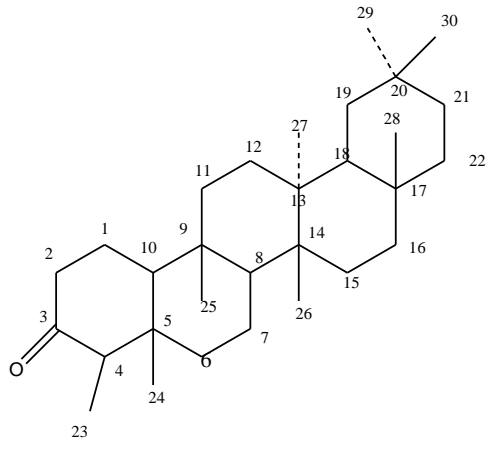

B

Figure 3. Structure of (A) 3-epi-betulinic acid, (B) D.A-friedo-oleanan-3-on

The chemical shifts in the ${ }^{1} \mathrm{H}-\mathrm{NMR}$ and ${ }^{13} \mathrm{C}$-NMR spectra of compound 1,2 and 3 closely resembled those of triterpene derivatives. On the basis of this evidence the structure of compound 1 was established as maytenfoliol, compound 2 as 3epi-betulinic acid and compound 3 as D.A-friedooleanan-3-on, which were found to be known compounds.

The present anticancer evaluation principles from $C$. tetrapterum has led to the finding of maytenfoliol, and from C. tomentosum has led to the finding of 3-epibetulinic acid and from $C$. moonii has led to D.A-friedo-oleanan-3-on derivates. Among the triterpene which had moderate-to-highest anticancer activity on Hela cell line cancer.

Anticancer activity assay was measured using Yoo. T.J (1999) method. The result can be displayed in the Tables III, IV and V. 3-epibetulinic acid exhibited a significant best anticancer activity against Hela cell lines compared to maytenfoliol and D.A-friedo-oleanan-3-on compounds. 3epibetulinic acid, maytenfoliol and of D.A-friedooleanan-3-on tested exhibited a significant activity in this assay since these compound inhibited 50\% of the cellular growth at concentration from 4 to 8 $\mu \mathrm{g} / \mathrm{mL}$, According to $\mathrm{IC}_{50}$ values showed that all of compounds most potential as cancer drug candidate.

Table III. Anticancer activity of maytenfoliol (TL8-9) by Hela cell line

\begin{tabular}{|c|c|c|c|c|c|}
\hline \multirow{2}{*}{$\begin{array}{l}\text { Dosage } \\
(\mu g / m L)\end{array}$} & \multicolumn{3}{|c|}{ Cell $\times 10^{4}$} & \multirow{2}{*}{$\%$ inhibition } & \multirow{2}{*}{$\mathrm{IC}_{50}(\mu \mathrm{g} / \mathrm{mL})$} \\
\hline & I & II & Mean & & \\
\hline 6.4 & 41 & 43 & 42.0 & 58.21 & \multirow{4}{*}{4.89} \\
\hline 3.2 & 60 & 59 & 59.5 & 40.80 & \\
\hline 1.6 & 70 & 73 & 71.5 & 28.86 & \\
\hline 0.8 & 90 & 92 & 91.0 & 9.45 & \\
\hline
\end{tabular}


Table IV. Anticancer activity of 3-epibetulinic acid by Hela cell line

\begin{tabular}{cccccc}
\hline $\begin{array}{c}\text { Dosage } \\
(\mu \mathrm{g} / \mathrm{mL})\end{array}$ & \multicolumn{3}{c}{ Cell $\times 10^{4}$} & \% inhibition & $\mathrm{IC} 50(\mu \mathrm{g} / \mathrm{mL})$ \\
\cline { 2 - 4 } & $\mathrm{I}$ & $\mathrm{II}$ & Mean & & 75.12 \\
3.4 & 24 & 27 & 25.5 & 50.24 & \\
1.6 & 49 & 53 & 51.0 & 35.61 & 3.17 \\
0.8 & 67 & 65 & 66.0 & 20.49 & \\
0 & 80 & 83 & 81.5 & & \\
\hline
\end{tabular}

Table V. Anticancer activity of D.A-friedo-oleanan-3-on by Hela cell line

\begin{tabular}{|c|c|c|c|c|c|}
\hline \multirow{2}{*}{$\begin{array}{l}\text { Dosage } \\
(\mu \mathrm{g} / \mathrm{mL})\end{array}$} & \multicolumn{3}{|c|}{ Cell $\times 10^{4}$} & \multirow{2}{*}{$\%$ inhibition } & \multirow{2}{*}{$\mathrm{IC}_{50}(\mu \mathrm{g} / \mathrm{mL})$} \\
\hline & I & II & Mean & & \\
\hline 6.4 & 49 & 47 & 48.0 & 53.40 & \\
\hline 3.2 & 62 & 63 & 62.5 & 39.32 & \\
\hline 1.6 & 81 & 83 & 82.0 & 20.39 & 5.63 \\
\hline 0.8 & 91 & 94 & 92.5 & 10.19 & \\
\hline 0 & 102 & 104 & 103 & & \\
\hline
\end{tabular}

Note: $\mathrm{IC}_{50}<4 \mu \mathrm{g} / \mathrm{mL}$ is highly cytotoxic, $\mathrm{IC}_{50}$ of $4-30 \mu \mathrm{g} / \mathrm{mL}$ is moderately cytotoxic, while $\mathrm{IC}_{50}>40 \mu \mathrm{g} / \mathrm{mL}$ is weakly cytotoxic

\section{CONCLUSION}

All of compounds have anticancer activity, epibetulinic acid obtained from the $C$. tomentosum Weigh is more active than maytenfoliol and D.Afriedo-oleanan-3-on, with an $\mathrm{IC}_{50}$ value were $3 ., 17 \mu \mathrm{g} / \mathrm{mL}, 4.89 \mu \mathrm{g} / \mathrm{mL}$ and $5.63 \mu \mathrm{g} / \mathrm{mL}$, respectively. Conclusion that all of compounds most potential as cancer drug candidate.

\section{ACKNOWLEDGEMENT}

The authors are grateful to Mr Suhandafor bioassay and Sofa Fajriah for the NMR measurement and Puspa Dewi for MS measurement and thanks are due to Mr. Ismail Rahman at the Herbarium Bogor Research
Institute - LIPI Bogor for identifying the plant material, and also to Reseach Centre for Chemistry - LIPI for a research support.

\section{REFERENCES}

Krupp, M.A.K. and Chatton, M. J., 1979, Current Medical Diagnosis Treatment Lange Medicinal Publication Los Altos, Calofornia 94022, 184-199.

Ross, R., 1993, The Pathogenesis of Atherosclerosis: a Perspective for the 1990s, Nature, 362, 80 I-808.

Taher., Idris, S., Ahmad and Arbain, D., 2005, A polyisoprenylated ketone from Calophyllum enervosum, Phytochemistry, 66, 
723-726.

Itoigawa, M., Ito, C., Tan, H.T.W., Kuchide, M., Tokuda, H., Nishino, H. and Furukawa, H., 200I, Cancer Chemopreventive agents, 4phenylcoumarins from Calophyllum inophyllum, Cancer letters., 169(I), I5-19.

Guilet, D., Seraphin, D., Rondeau, D., Richomme, P. and Bruneton., 200I, Cytotoxic coumarins from Calophyllum dispar. Phytochemistry., 58, 57I-575.

Soerianegara and Lemmens, R.H.M.J., 1994, Plant Resources of South-East Asia, Timber trees mayor commercial timbers, Bogor. Indonesia, Prosea., I (5), I I4- I 32.

Sung, T.V., Steglich, W., and Adam, G., 1991, Triterpene glycosides from Schefflera octophylla, Phytochemistry., 7(30), 2349-
2356.

Herz, Santhanam, and Wahlberg, 1972, 3-epibetulinic acid, a new triterpenoid from Picramnia pentandra, Phytochemistry, II, 306 I-3063.

Garmen, Lucia, Faria, G., Correa, P., Possenti, A. and Ernesto, J., 2000, Evaluation of the antiulcerogenic activity of friedelin-3ß-ol and friedelin isolated from Maytenus ilicifolia (Celastraceae), Journal Ehno Pharmacology, 72, 465-468.

Yoo, T.J., Yoo, Y.C., Kang, T.B., Shimazaki, K., Song, S.K., Lee, K.H, Kim, S.H., Park, C.H., Azuma, I. and Kim, J.B., 1999, Lectins Isolated from Korean mistletoe (Viscum album coloratum) induce apoptosis in tumor cells, Cancer Letter, I36(I), 33-40. 